\title{
Channel pattern of proglacial rivers: topographic forcing due to glacier retreat
}

\section{Philip M. Marren* and Shamus C. Toomath}

Department of Resource Management and Geography, The University of Melbourne, Parkville, 3010, Australia

*Correspondence to P. Marren, Department of Resource Management and Geography, The University of Melbourne, Parkville, 3010, Australia. E-mail: pmarren@unimelb.edu.au

ABSTRACT: Glacier retreat leads to changes in channel pattern during deglaciation, in response to changing water, sediment and base level controls. Recent ongoing retreat at Skaftafellsjökull, Iceland (c. $50 \mathrm{~m}$ per year since 1998) has resulted in the formation of a sequence of river terraces, and several changes in river channel pattern. This paper compares widely used models of river channel pattern against the changes observed at Skaftafellsjökull. Doing this reveals the role of topographic forcing in determining proglacial channel pattern, whilst examining the predictive power and limitations of the various approaches to classifying river channels. Topography was found to play a large role in determining channel pattern in proglacial environments for two reasons: firstly, glacier retreat forces rivers to flow through confined moraine reaches. In these reaches, channels which theory predicts should be braided are forced to adopt a single channel. Secondly, proximal incision of proglacial rivers, accompanied by downstream aggradation, leads to changes in slope which force the river to cross channel pattern thresholds. The findings of this work indicate that in the short term, the 
majority of channel pattern change in proglacial rivers is due to topographic forcing, and that changes due to changing hydrology and sediment supply are initially relatively minor, although likely to increase in significance as deglaciation progresses. These findings have implications for palaeohydraulic studies, where changes in proglacial channel pattern are frequently interpreted as being due to changes in water or sediment supply. This paper shows that channel pattern can change at timescales faster than hydrological or sediment budget changes usually occur, in association with relatively minor changes in glacier mass balance.

KEYWORDS: Iceland; glacier recession; braided river; stream power; deglaciation

\section{Introduction}

Proglacial river channels are commonly regarded as being dominated by braided channels (Krigström, 1962; Maizels, 1995; Marren, 2005). Indeed, many models of braided river sedimentation have been developed using proglacial rivers (Miall, 1977; Boothroyd and Nummedal, 1978). The tendency for channels to be braided is because proglacial environments tend to have steep channel slopes, high, and highly variable meltwater discharge, an abundance of coarse-grained sediment and erodible banks (Boothroyd and Nummedal, 1978; Röthlisberger and Lang, 1987; Bridge, 1993). Despite these generalisations, proglacial channels are subject to the same hydraulic and sediment controlled drivers of channel pattern common to all rivers and can have a diverse range of morphologies (Marren, 2004), due to a wide range of gradients, sediment regimes and geological controls. Because of this diversity of boundary conditions, many channel types have been observed in 
proglacial settings, including single channel, braided and anastomosing, and with channel bed and bank material ranging in size from boulder to silt and clay.

Channel pattern changes during deglaciation are thought to be controlled by changing water and sediment fluxes driving a change from braiding dominated rivers, to single-thread channels (Maizels, 1983; Gurnell et al., 2000). Conceptual models of this kind usually assume that reaches which are located far downstream from the glacier are more likely to be single-thread, and that the transition from single-thread to braided will move upstream, with the proximal reaches which are in close contact with the glacier remaining braided the longest.

Over long timescales, changes in water and sediment flux during glacier retreat clearly play a dominant role in determining channel pattern, and drive channel pattern changes. Reconstructions of formerly glaciated landscapes often use change in hydrology, inferred from palaeochannel characteristics to determine changes in glacial meltwater runoff rates, and glacier mass balance (Maizels, 1983). What is often overlooked is that in the short term, glacier retreat forces river channels to undergo topographic changes which may play a role in determining channel pattern. For instance, constriction of a river channel behind a moraine system may force rivers to flow parallel to the glacier rather than directly away from it. Rivers may become confined, and steepen where they cut through a moraine belt formed during glacier retreat (Marren, 2004).

A second way in which topographic forcing can alter proglacial channel patterns is through channel incision. Where proglacial river channels are fully alluvial, glacier retreat usually triggers incision and terrace formation (Thompson and Jones, 1986; Wilkie and Clague, 2009). Close to the glacier margin, incision is triggered by the lowering of the upstream end of the long profile as the glacier retreats away from an ice-contact slope (Thompson and Jones, 1986; Marren, 2002). This type of proximal incision usually happens 
rapidly, with significant incision occurring annually as the proglacial channel network reorganises itself in response to glacier retreat (Marren, 2002). Similar channel incision has also been documented in response to glacier floods (Maizels, 1987; Marren et al., 2009).

Channel slope is a primary control on river channel pattern (Leopold and Wolman, 1957). Even where discharges and sediment loads remain the same, lowering the channel slope via channel incision will reduce stream power and shear stress, and if critical thresholds are crossed, channel pattern will change (Ferguson, 1987; Dade and Friend, 1998; Church, 2002). It is therefore possible that proglacial channel changes are driven in the first instance by topographic changes forced by adjustment to glacier retreat, with the channel bed lowering as the river is forced to cut through an ice-contact slope. This is significant because discharges may to rise for several decades as melt rates increase (Hock et al., 2005), whilst sediment supply rates may take decades or centuries to decline from their glacial period peak (Church and Ryder, 1972). The transition to a single-thread channel may therefore be rapidly initiated by changes in slope, and only decades later reinforced by reductions in discharge and sediment supply.

The aim of this paper is to assess the role of glacier-retreat induced topographic forcing in changing channel pattern of proglacial rivers using the example of Skaftafellsjökull, Iceland. Over the past decade, the retreat of Skaftafellsjökull, and the associated proglacial channel changes have been well documented (Marren, 2002; Marren and Toomath, 2013). In this study, widely used predictors of channel pattern, which incorporate channel or valley slope will be used to assess whether the observed reduction in slope was sufficient to change the channel pattern. These predictions will be compared with the actual channel changes to assess the extent to which channel change is being controlled by topographic forcing. 


\section{Study area}

Skaftafellsjökull is located in southeast Iceland, and is an outlet glacier sourced from the Öræfajökull and Vatnajökull icecaps (Fig. 1). The glacier margin is located at c. $120 \mathrm{~m}$ above sea level, terminating at an extensive gravel outwash plain which merges with the Skeiðarársandur outwash plain and extends to the sea. The modern proglacial environment is confined within a moraine belt formed during the Little Ice Age re-advance of the glacier (Thompson, 1988). Near Skaftafellsjökull glacier margin the outwash plain is 80 to $170 \mathrm{~m}$ thick (Guðmundsson et al., 2002). As the glacier is based on sediment, not bedrock, a pronounced ice-marginal overdeepening has developed (Tweed et al., 2005). In this setting, glacier retreat leads to either river channel incision and terrace formation, or the development of proglacial lakes. Skaftafellsjökull is approximately $2 \mathrm{~km}$ wide, and until recently, was drained by two rivers, sourced from the east and west ends of the glacier margin, which join together just upstream of the Highway 1 road bridge (Fig. 2).

Skaftafellsjökull has retreated approximately $2300 \mathrm{~m}$ since 1904, the date of the first topographic maps of the region (Thompson, 1988). Annual measurements of the position of the glacier have been made since 1932, and have been made from the same location since 1942 (Thorarinsson, 1956; Sigurðsson, 1998; Fig. 3). Skaftafellsjökull retreated steadily from 1904 to 1970 , with only minor readvances. The average rate of retreat was $72 \mathrm{~m}$ per year from 1934 to 1942, and 30 m per year from 1942 to 1970. Readvance occurred from 1971 to 1988, with the glacier advancing in most years, resulting in a total readvance of $96 \mathrm{~m}$. From 1989 to 1995 there was 136 m of retreat, and in 1996 to 1998 the glacier advanced a total of $90 \mathrm{~m}$. Since 1999, the glacier has retreated every year, with an average retreat rate of $53 \mathrm{~m}$ 
per year. The impact of the glacier fluctuations on proglacial rivers from 1996 to 2011 have been described by Marren (2002) and Marren and Toomath (2013).

In the most recent retreat phase (1999 onward), the first five years were associated with terrace formation in the proximal zone of the western outlet channel (Fig. 4). Incision occurred rapidly, on an annual basis. The zone of incision extended from the glacier margin to the first belt of encircling moraines. Downstream of these moraines, the channel remained largely unchanged. From 2004 onward, a proglacial lake developed at the ice margin, becoming progressively larger over time (Schomaker, 2010). Continued retreat of the ice margin down the ice-contact slope meant that the lake surface lowered as the glacier retreated and the lake area extended. Some incision of the river channel downstream of the lake outlet occurred, but most change occurred because of a large rainstorm flood in December 2006 (Marren and Toomath, 2013), which removed material from the moraine belt, and deposited it in the unconfined reach upstream of the Highway 1 bridge. In 2010, the lake extended across the full length of the ice margin, allowing water to drain via the eastern river channel. Because of this, the lake level fell below the western outlet, which led to the abandonment of the western river channel, meaning that all meltwater now drains via the eastern channel.

\section{Channel pattern discrimination}

The controls on channel pattern are complex, and go far beyond the kind of analysis that is possible with bivariate empirical correlations and regression (Thorne, 1997; Kleinhans, 2010). Despite this there is a long tradition of explaining the characteristics of rivers in terms of the flux of water and sediment, and adjustments to equilibrium conditions (Lane, 1955; Schumm, 1985; Latrubesse, 2008). The intention of this paper is not to test or critique 
methods of discriminating different channel patterns, but to use a number of widely accepted methods to test the role of glacier retreat induced topographic changes on channel pattern. Although all of the common methods of discriminating channel pattern incorporate slope in some way, the slope-discharge discrimination of Leopold and Wolman (1957) is, conceptually, probably the least powerful method (Ferguson, 1987; van den Berg, 1995); most other techniques incorporate sediment, and some measure of force such as stream power. In order to test how significant slope changes are in determining channel pattern, a range of widely applied methods will be selected from the literature.

Discharge-slope (Q-s) analyses of the type produced by Leopold and Wolman (1957) represent the simplest way of discriminating between braided and meandering channels. This approach has been repeated by other workers, using different data sets, and different definitions of significant discharge. Summaries of these analyses can be found in Ferguson (1987), Bridge (1993) and Thorne (1997). The main limitations of this approach are that they do not explicitly incorporate sediment as a controlling variable of channel pattern, and that they have tended to search for a threshold in what may be a continuum of channel change (Carson, 1984).

Discharge and slope together form the major variables in the stream power equation. A logical extension of the Leopold and Wolman (1957) analysis is therefore to assume that channel pattern changes in response to increases in stream power, usually unit (or specific) stream power which is total stream power per unit bed area:

$\omega=\frac{\rho g Q s}{w}$

where $\mathrm{Q}$ and s are discharge and slope, $\rho$ is the density of water, and $\mathrm{g}$ is the acceleration due to gravity. Schumm $(1981,1985)$ suggests that stream power and sediment size and load 
increase together, as the tendency for braiding increases, and Ferguson (1987) expresses Schumm's ideas as a qualitative bivariate plot. Typical width-depth ratios associated with different channel types are given by Schumm (1977, 1985), and ranges of stream power associated with different channel and floodplain types are defined by Nanson and Croke (1992). More recently, Dust and Wohl (2010) used a stream power-W/d ratio plot to define stable and unstable, and braided and non-braided fields for non-armoured coarse-grained floodplains. Building on the stream power approach, van den Berg (1995) used plots of stream power against grain size to discriminate between braided and meandering channels. The intention of the van den Berg (1995) approach is to determine the potential for a particular channel pattern to occur. Because channel slope is strongly influenced by increased sinuosity, valley slope is used instead of channel slope, and unit stream powers are calculated using channel widths calculated from hydraulic geometry relations rather than observed widths. This approach results in channels plotting in different positions than they would if observed values were used (Lewin and Brewer, 2001) but is defended by van den Berg and Bledsoe (2003) as it considers what the channel should be in the absence of confounding factors. Kleinhans and van den Berg (2011) compared the van den Berg (1995) approach to physics-based bar pattern prediction methods (Struiksma et al., 1985), and found that the empirical method performed marginally better, as bank strength is indirectly incorporated.

An alternative approach to channel pattern prediction is the theoretical stability analysis of the type produced by Parker (1976), which is usually used in conjunction with the gravel bed river hydraulic geometry relations of Parker (1979). Braiding is dependent on a critical value of slope and Froude (Fr) number, with the meandering - braided threshold occurring when $\mathrm{w} / \mathrm{d} \approx \mathrm{Fr} / \mathrm{s}$. This approach is limited by the dependence on channel dimensions derived from hydraulic geometry relations (Ferguson, 1987), and the predictions do not agree very well with field data (Bridge, 1993). 
Four distinct methods of discriminating channel pattern are outlined above (discharge/slope, stream power/width-depth ratio, stream power/grain size, slope-Froude number/depth-width ratio). All of them incorporate channel or valley slope, and a range of hydraulic, sedimentary and channel parameters. It is anticipated that channel pattern will be more sensitive to incision and slope reduction where slope is directly used in the discrimination method, but may be less sensitive in methods incorporating a larger range of parameters.

A difficultly with many of the methods of channel pattern discrimination developed in the literature is that many of the variable used are not independent. As sinuosity increases, channel slope is not independent of channel pattern (Carson, 1984; van den Berg, 1995). In this study, which is mainly concerned with low sinuosity braided and single channel rivers this is not a major issue. Channel width and depth are dependent on both discharge (Leopold and Maddock, 1953) and grain size (Leopold and Maddock, 1953; Wilcock, 1971; Parker, 1979). Unit stream power and width-depth ratio are therefore partly outcomes of channel pattern rather than predictors of channel pattern. Despite the limitations to these methods, they have been widely used in the literature, allowing for ready comparison with the data presented here. An additional factor which has not been explicitly included in the methods outlined above is bank erodability, which is thought to be a significant factor in channel pattern (Carson, 1984; Ferguson, 1987). This is not a significant issue in this study for two reasons. Firstly, in non-cohesive sediment, bank erodability is not independent of grain size, so is largely incorporated into analyses which incorporate sediment size. Secondly, in many landscapes, variations in bank erodability are largely due to variations in vegetation cover (Coulthard, 2005; Tal and Paola, 2007). Similarly, vegetation is thought to play a large role in maintaining floodplain surface stability, which prevents the development of chute cutoffs, and ultimately, braiding (Tal and Paola, 2010), although floodplain stability can also be 
maintained by sufficiently cohesive floodplain sediments (van Dijk et al., 2013). In this region of SE Iceland, almost all channels are coarse-grained and devoid of both vegetation and fine-grained cohesive sediment, reducing their impact as variables in the analysis.

\section{Methods}

Data were gathered with the intention of applying the channel pattern discrimination methods outlined above to the channels at Skaftafellsökull. Data needed include discharge, slope, channel width and depth, and representative grain size. From these data, unit stream power can be calculated using the equation given above. Channel slopes (equivalent to valley slopes because of the low sinuosity) were surveyed in 2011, along the western and eastern river channels, and along the proximal terraces formed during 1998 to 2003. Representative grain size data was collected using a Wolman (1954) pebble count of the b-axis of 100 clasts, at $100 \mathrm{~m}$ intervals along all of the surveyed channels (for a total of 53 pebble counts). Each pebble count sampled surface sediment over an approximately $2 \mathrm{~m}^{2}$ area in the centre of abandoned channels, and on bar surfaces for active channels. The 1998 to 2003 terraces are now highly fragmented and heavily modified, with sediment from one terrace frequently incorporated into the terrace below, and some surfaces buried by glacial, deltaic or lacustrine deposits. It was therefore not possible to determine separate grain sizes for each terrace. However, because each terrace is reworking the same coarse upper outwash surface, it was assumed that grain size did not vary significantly over this period.

Discharges and channel dimensions were estimated using a variety of methods, as there is no gauging station on the Skaftafellsá and not all of the channels were active or intact at the time of survey. For channels which had been abandoned by 2011 but which retained a 
clear channel form, bankfull channel form was surveyed, and discharges calculated using the Manning equation. The discharge of the proximal channel last active in 2001, and the main western channel last active in 2009 was estimated in this way. Values of Manning's ' $n$ ' were estimated using the Bray (1979) equation, which used hydraulic radius (or average depth) and average grain size, and was calibrated for gravel-bed rivers with similar dimensions and grain-sizes to those found in the study area.

For channels which had been largely removed, preventing an estimate of the former channel dimensions being made, discharges were assumed to increase each year by one percent, using the calculated discharges from the channels with clear remains as a starting point. A compounded one percent per year increase in discharge is in accord with estimates produced from modelling of mass balance changes of southern Vatnajökull for the period 1990 to 2020 by Aðalgeirsdóttir et al. (2006), and is internally consistent, since the discharge estimated from the channel active in 2001 becomes almost identical to that of the channel active in 2009 when increased in this way. Channel widths were measured in the field and using georeferenced aerial photography and Google Earth ${ }^{\mathrm{TM}}$ imagery (from 1997, 2003 and 2008). Discharges and widths of the 1998 to 2003 surfaces (with the exception of the 2001 terrace, which was surveyed) were estimated using this combination of extrapolated discharges and widths measured from aerial imagery. Depths of the 1998 to 2003 channels were estimated using a hydraulic geometry relation derived from all of the surveyed cross sections and their estimated discharges. Channel flow velocity of the 1998 to 2003 surfaces was then back-calculated from discharge, width and depth. Discharge of the eastern channel in 2011 was estimated by salt dilution gauging. Water velocity was estimated at the time of the dilution gauging using the time it took the salt wave to pass a known distance. Measurements were taken on three occasions, over one week in June, at a site on the eastern channel upstream of the Highway 1 road bridge. Measurements were taken in the afternoon, 
and represent mid-summer below average discharge rates, in non-flood (no rainfall) conditions. Poor salt mixing in the low temperature water may have resulted in inaccuracies in the discharge estimates. Widths of the eastern channel were taken from aerial imagery. Knowing discharge, width and velocity, allowed average depths to be back-calculated. Average depth was assumed to be equivalent to hydraulic radius, a common assumption in studies of channel pattern (Dade and Friend, 1998), and reasonable for the relatively wide, shallow channels examined in this study.

\section{Results}

\section{Summary of observed channel slope and morphology changes}

The slopes of the major proglacial channels at Skaftafellsjökull are shown in Figure 5. Although incision occurred between 2003 and 2010, the slope of the western channel remained constant over time (Fig. 5a). The western channel is confined by moraines close to the glacier, but is much less confined downstream of this. In 2003 the unconfined section was braided, but by 2008 , the extent of the braided reach was much smaller (Fig. 2). The eastern channel is much flatter than the western channel. It flows between low, degraded moraines and has maintained a dominantly single channel pattern since 1996, apart from a short braided section halfway between the glacier and the junction with the western channel (Fig. 2). The long profiles of the proximal terraces and terrace fragments are shown in Figure 5b. In 1998 the proximal sandur was braided, following a period of readvance. The onset of glacier retreat in 1999 triggered incision which confined the channel, and in 2001 the channel 
switched from in front of the 1998 moraine to behind it. By 2004, lake development prevented any further incision of the proximal river channel.

\section{Predicted channel patterns}

The channel pattern discrimination methods outlined above were used to predict channel pattern for the three main reaches of the Skaftafellsjökull proglacial landscape, using slopes and discharges covering the period 1998 to 2009 (Table 1; Fig. 6). The reaches plotted are: the eastern channel, the western channel in 2003 and 2009 (periods with relatively high and low degrees of braiding, respectively) and the proximal channel over the period 1998 to 2003 (during the period of incision). Generally, the reached-averaged mean values used represent the channels well (Table 1), although there is greater variability in the proximal terrace sites compared to the main western channel, and the eastern channel.

Overall, all of the plots discriminate between the western and eastern channels, with the western channel tending to plot in, or close to the braided region, while the eastern channel plots in the meandering zone. In the stream power-grain size plot (Fig. 6d), all the points plot in the meandering zone. This appears to be because stream power is underestimated for the observed grain sizes. This may be due to the variability in grain size observed across the area (Table 1), reflecting numerous clasts which are only transported during peak discharges, but which were included in the grain-size sampling. Nonetheless, the distinction between the eastern and western channels is similar to the other plots. The impact of slope changes on plotting position is clear. In the slope-discharge plot (Fig. 6a) the reduction in slope as the terrace incises moves the proximal channel from the braided region closer to the meandering region. The channel plots as braided, although in reality it was a single channel, with widely spaced individual braids from 1999 onward, indicating that the 
channel pattern is being dictated by topography. The increase in discharge over the same period did not compensate for the reduction in slope.

The Parker (1976) stability analysis puts the western channel close to the braided region and the eastern channel well into the meandering region (Fig. 6b). In all cases, the slope-Froude number ratio is largely invariant, with most of the discrimination due to changes in width-depth ratio. The proximal terrace sequence plots in or close to the braided region in 1998 to 2000, with changes mostly controlled by the width-depth ratio changes associated with the switch from braided to meandering. From 1999 onwards, reductions in slope due to the terrace incision progressively place the channel further into the meandering region. The eastern channel sits closer to the other channels than in the other methods, indicating that hydraulically, it is fairly similar.

Incorporating sediment, via the van den Berg (1995) plot (Fig. 6d) makes little difference to the channel discrimination, with the eastern, western and proximal channels plotting in similar positions to the slope-discharge plot. Because it is assumed that grain size is invariant, the main driver of change in the incising proximal channels is the lowering of slope, reducing stream power. Again, the increases in discharge over the same period have no effect compared to the slope changes. Using width-depth ratio instead of grain size (Fig. 6c) should produce similar results to Figure 6d, as in gravel bed rivers, grain size is the major control on width-depth ratio (assuming discharge is unvaried) (Parker, 1979). In practice, there are differences because grain size was not varied in Figure 6d, and because observed width-depth ratios were controlled by confining moraines. In general though, the eastern and western channels can be clearly distinguished, with the eastern channel having a lower stream power, and being relatively narrow compared to the western channel. As with Figure $6 \mathrm{~b}$, the width-depth ratio of the proximal terrace sequence reduces markedly from 1998 to 1999 
because of the switch from a braided to a meandering channel whilst from 1999 to 2003, the plotting position changes mostly because of slope controlled reductions in stream power.

\section{Discussion}

The slope-discharge plot was the most effective in demonstrating the extent to which shortterm channel pattern changes in proglacial environments are driven by slope changes. As slope decreased, the channel plotted progressively closer to the meandering threshold, although in reality it had become a single channel close to the start of the study period. Over the same time period, the increase in discharge due to increased melt rates has no impact on channel pattern. The other channel pattern discrimination methods highlight the more complex reality, where channel pattern is controlled by a range of factors, particularly sediment. Interestingly, the other methods plotted most of the channels just below the braiding threshold. What is apparent is that it can be hard to predict what the channel pattern would be in the absence of confining moraines. Channel pattern theory assumes unconstrained alluvial systems, whilst glacial landscapes, even unconsolidated outwash plains, impose topographic constraints. It is interesting to ask what form the channel would take in the absence of these constraints, and which methods of channel pattern discrimination are most effective at determining this. Whilst Figures $6 \mathrm{~b}$ and $6 \mathrm{c}$ both show clear discrimination of the single thread eastern channel and the braided or close to braided western channel, using width-depth ratio, the problem of choosing to use observed or predicted widthdepth ratios limits the utility of these methods. Observed width-depth ratios are likely to be influenced by confining moraines or terraces, whilst using a hydraulic geometry relation results in limited site specific applicability. A similar problem occurs with using specific 
stream power as a predictor. Using observed widths for braided channels will result in estimates of stream power which are too low, whilst avoiding this problem by estimating channel width using hydraulic geometry reduces the likelihood that the prediction is relevant to a particular river channel. Ultimately, for answering the question 'what channel pattern would this river have in the absence of confining moraines?' without resorting to physically based models, the slope-discharge discrimination function may still be the most effective (Eaton et al., 2010).

Palaeohydraulic reconstructions are often used as a basis for climate reconstructions, and often rely heavily on changes in channel pattern to infer changes in discharge, and hence climate (e.g. Kozarski, 1983; Maizels and Aitken, 1991). Given the rate that discharges change during deglaciation, the rate at which stored sediment is released, and the rate at which vegetation encroaches onto exposed proglacial landscapes and stabilises them, it is likely that a switch from a braided to a meandering system would take a decade or more (Gurnell et al., 2000). This study has shown that by rapidly reducing channel slopes in proximal settings, topographic forcing can produce a braided to meandering transition in less than a decade. Because the channel incision is happening in response to glacier retreat (Marren and Toomath, 2013), topographic forcing is still a response to climate change, but the mass balance changes associated with the channel pattern changes are trivial. Caution should therefore be used when interpreting formerly glaciated landscapes which show evidence of channel pattern change, as it may not always be reasonable to infer significant changes in hydrology or rapid changes in glacier mass balance at the time of the channel pattern transition.

\section{Conclusions}


There are at least two ways in which topographic forcing of river channel pattern can occur in proglacial landscapes. The first type of topographic forcing is channel confinement, where the river is forced to flow between moraines, or is confined by terraces. Channel confinement can result in a single thread channel where the prevailing hydraulic and sedimentary conditions would otherwise produce a braided channel. The presence of channel confinement is not in itself surprising, although it can confound palaeoenvironmental reconstructions if it is not taken into account. The second type of topographic forcing is the rapid reduction in slope which occurs when a proglacial channel incises in response to upstream lowering of the long profile during glacier retreat down a sediment-based ice-marginal overdeepening. This second type of topographic forcing can confine the channel, but more significantly, the reduction in slope decreases the energy available to the river, and reduces the potential for braiding, irrespective of the degree of confinement. The ice-proximal reduction, and distal increase in braiding are similar to the modelled findings of Germanoski and Schumm (1993), although in their study the upstream degradation was due to a reduction in sediment input, which in the proglacial environment occurs when sediment is trapped by proglacial lakes (Chew and Ashmore, 2001).

Channel pattern prediction in proglacial environments is confounded by the high degree of topographic forcing: channels which 'should' be braided are often single channel. Despite the fact that the constrictions are usually formed of sediment rather than bedrock, the effects of this topographic forcing can persist for decades, or even centuries following deglaciation. Topographic forcing of this kind should therefore be considered a paraglacial phenomenon, as it represents an effect of glaciation persisting long after the glacier has melted. 
Palaeohydraulic reconstructions and interpretations of channel pattern changes during the Quaternary are usually interpreted in terms of changes in discharge and sediment. The timescales over which deglaciation occurs, and the long time lags over which sediment fluxes change in proglacial landscapes, result in changes in response to water and sediment fluxes occurring over relatively long time periods (10s to 100 s of years). Significant changes in channel pattern can occur over much shorter time scales (5 to 10 years) in response to topographic forcing. Palaeohydraulic interpretations of channel pattern changes need to be mindful of the fact that proximal proglacial river channels can change dramatically in response to relatively minor changes in glacier mass balance.

Acknowledgements-Fieldwork in Iceland from 1998 to 2003 was supported by an Earthwatch grant awarded to Dr Andrew J. Russell. Earthwatch volunteers are thanked for assistance with data collection. Fieldwork in 2004 was assisted by Mandy Winstanley, and fieldwork in 2011 was assisted by Louisa Davis and Richard Marren.

\section{References}

Aðalgeirsdóttir G, Jóhannesson T, Björnsson H, Pálsson F, Sigurðsson O. 2006. Response of Hofsjökull and southern Vatnajökull, Iceland, to climate change. Journal of Geophysical Research 111: F03001, doi:10.1029/2005JF000388.

Boothroyd JC, Nummedal, D. 1978. Proglacial braided outwash: a model for humid alluvial fan deposits. In Fluvial Sedimentology, Miall, AD (Ed) Canadian Society of Petroleum Geologists, Memoir 5; 641-668. 
Bray DI. 1979. Estimation of average velocity in gravel-bed rivers. ASCE Journal of the Hydraulics Division 105(HY9): 1103-1122.

Bridge JS. 1993. The interaction between channel geometry, water flow, sediment transport and deposition in braided rivers. In Braided Rivers, Best JL, Bristow, CS (Eds) Geological Society, London, Special Publication 75, 13-71.

Carson MA. 1984. The meandering-braided river threshold: a reappraisal. Journal of Hydrology 73: 315-334.

Chew LC, Ashmore PE. 2001. Channel adjustment and a test of rational regime theory in a proglacial braided stream. Geomorphology 37: 43-63.

Church M. 2002. Geomorphic thresholds in riverine landscapes. Freshwater Biology 47: $541-557$.

Church M, Ryder JM. 1972. Paraglacial sedimentation: a consideration of fluvial processes conditioned by glaciation. Geological Society of America Bulletin 83: 3059-3072.

Coulthard TJ. 2005. Effects of vegetation on braided stream pattern and dynamics. Water Resources Research 41: W04003.

Dade WB, Friend PF. 1998. Grain-size, sediment-transport regime, and channel slope in alluvial rivers. The Journal of Geology 106: 661-675.

Dust DW, Wohl EE. 2010. Quantitative technique for assessing the geomorphic thresholds for floodplain instability and braiding in the semi-arid environment. Natural Hazards 55:145-160.

Eaton BC, Millar RG, Davidson S. 2010. Channel patterns: Braided, anabranching, and single-thread. Geomorphology 120: 353-364.

Ferguson R. 1987. Hydraulic and sedimentary controls of channel pattern. In River Channels: Environment and Process, Richards K (Ed) Institute of British Geographers, Special Publication Series 17; 129-158. 
Germanoski D, Schumm SA. 1993. Changes in braided river morphology resulting from aggradation and degradation. Journal of Geology 101: 451-466.

Gurnell AM, Edwards PJ, Petts GE, Ward JV. 2000. A conceptual model for alpine proglacial river channel evolution under changing climatic conditions. Catena 38: 223 242.

Guðmundsson MT, Bonnel, A, Gunnarsson K. 2002. Seismic soundings of sediment thickness on Skeiðarársandur, SE-Iceland. Jökull 51: 53-64.

Hock R, Jansson P, Braun LN. 2005. Modelling the response of mountain glacier discharge to climate warming. In Global Change and Mountain Regions: an Overview of Current Knowledge, Huber UM, Bugmann HKM, Reasoner MA (Eds) Springer, Dordrecht; 243252.

Kleinhans MG. 2010. Sorting out river channel patterns. Progress in Physical Geography 34: $287-326$.

Kleinhans MG, van den Berg JH. 2011. River channel and bar patterns explained and predicted by an empirical and a physics-based method. Earth Surface Processes and Landforms 36: 721-738.

Kozarski S. 1983. River channel adjustment to climatic change in west central Poland. In Background to Palaeohydrology: a Perspective, Gregory KJ (Ed) John Wiley \& Sons, Chichester, 355-374.

Krigström A. 1962. Geomorphological studies of sandur plains and their braided rivers in Iceland. Geografiska Annaler 44: 328-346.

Lane EW. 1955. The importance of fluvial morphology in hydraulic engineering. Proceedings of the American Society of Civil Engineers, 81(745): 1-17.

Latrubesse EM. 2008. Patterns of anabranching channels: The ultimate end-member adjustment of mega rivers. Geomorphology 101: 130-145. 
Leopold LB, Maddock TM Jr. 1953. The hydraulic geometry of stream channels and some physiographic implications. United States Geological Survey, Professional Paper, 252.

Leopold LB, Wolman MG. 1957. River channel patterns: braided, meandering and straight. United States Geological Survey, Professional Paper, 282-B.

Lewin J, Brewer PA. 2001. Predicting channel patterns. Geomorphology 40: 329-339.

Maizels JK. 1983. Proglacial channel systems: change and thresholds for change over long, intermediate and short timescales. In Modern and Ancient Fluvial Systems, Collinson JD, Lewin J (Eds), International Association of Sedimentologists, Special Publication 6; 251266.

Maizels JK. 1987. Large-scale flood deposits associated with the formation of coarse-grained braided terrace sequences. In Recent Developments in Fluvial Sedimentology, Ethridge FG, Flores RM, Harvey MD (Eds) Society of Economic Paleontologists and Mineralogists, Special Publication 39; 135-148.

Maizels, J.K., 1995. Sediments and landforms of modern proglacial terrestrial environments. In Modern Glacial Environments, Menzies J (Ed) Butterworth-Heinemann, Oxford; 365416.

Maizels JK, Aitken JF. 1991. Palaeohydraulic change during deglaciation in upland Britain: a case study from northeast Scotland. In Temperate Palaeohydrology, Starkel L, Gregory KJ, Thornes JB (Eds) John Wiley \& Sons, Chichester, 105-145.

Marren PM. 2002. Glacier margin fluctuations, Skaftafellsjökull, Iceland: implications for sandur evolution. Boreas 31: 75-81.

Marren PM. 2004. Present-day sandurs are not representative of the geological record. Sedimentary Geology 152, 1-5 (2002). Discussion. Sedimentary Geology 164: 335-340. Marren PM. 2005. Magnitude and frequency in proglacial rivers: a geomorphological and sedimentological perspective. Earth-Science Reviews 70: 203-251. 
Marren PM, Russell AJ, Rushmer EL. 2009. Sedimentology of a sandur formed by multiple jökulhlaups, Kverkfjöll, Iceland. Sedimentary Geology 213: 77-88

Marren PM, Toomath SC. 2013. Fluvial adjustments in response to glacier retreat: Skaftafellsjökull, Iceland. Boreas 42: 57-70.

Miall AD. 1977. A review of the braided river depositional environment. Earth-Science Reviews 13: 1-62.

Nanson GC, Croke JC. 1992. A genetic classification of floodplains. Geomorphology 4: 459486.

Parker G. 1976. On the cause and characteristic scales of meandering and braiding in rivers. Journal of Fluid Mechanics 76: 457-480.

Parker G. 1979. Hydraulic geometry of active gravel rivers. American Society of Civil Engineers, Journal of the Hydraulics Division 105: 1185-1201.

Röthlisberger H, Lang H. 1987. Glacial hydrology. In Glacio-Fluvial Sediment Transport: An Alpine Perspective, Gurnell AM, Clark MJ (Eds) John Wiley \& Sons, Chichester; 207284.

Schomacker A. 2010. Expansion of ice-marginal lakes at the Vatnajökull ice cap, Iceland, from 1999 to 2009. Geomorphology 119: 232-236.

Schumm SA. 1977. The Fluvial System. John Wiley \& Sons, New York; 338 pp.

Schumm SA. 1981. Evolution and response of the fluvial system, sedimentologic implications. In Recent and Ancient Nonmarine Depositional Environments: Models for Exploration, Ethridge FG, Flores RM (Eds), Society of Economic Paleontologists and Mineralogists, Special Publication 31; 19-29.

Schumm SA. 1985. Patterns of alluvial rivers. Annual Review of Earth and Planetetary Sciences 13: 5-27. 
Sigurðsson O. 1998. Glacier variations in Iceland 1930-1995 - from the database of the Icelandic Glaciological Society. Jökull 45: 3-25.

Struiksma N, Olesen K, Flokstra C, De Vriend H. 1985. Bed deformation in curved alluvial channels. Journal of Hydraulic Research 23: 57-79.

Tal M, Paola C. 2007. Dynamic single-thread channels maintained by the interaction of flow and vegetation. Geology 35: 347-350.

Tal M, Paola C. 2010. Effects of vegetation on channel morphodynamics: results and insights from laboratory experiments. Earth Surface Processes and Landforms 35: 1014-1028.

Thompson A. 1988. Historical development of the proglacial landforms of Svínafellsjökull and Skaftafellsjökull, southeast Iceland. Jökull 38: 17-31.

Thompson A, Jones A. 1986. Rates and causes of proglacial river terrace formation in southeast Iceland: an application of lichonometric dating techniques. Boreas 15: 231-246.

Thorarinsson S. 1956. On the variations of Svínafellsjökull, Skaftafellsjökull and Kvíarjökull in Öræfi. Jökull 6: 1-15.

Thorne, C.R., 1997. Channel types and morphological classification. In Applied Fluvial Geomorphology for River Engineering and Management, Thorne CR, Hey RD, Newson MD (Eds) John Wiley \& Sons, Chichester; 175-222.

Tweed FS, Roberts MJ, Russell AJ. 2005. Hydrologic monitoring of supercooled meltwater from Icelandic glaciers. Quaternary Science Reviews 24: 2308-2318.

Van den Berg JH. 1995. Prediction of alluvial channel pattern of perennial rivers. Geomorphology 12: 259-279.

Van den Berg JH, Bledsoe BP. 2003. Comment on Lewin and Brewer (2001): “Predicting channel patterns', Geomorphology 40, 329-339. Geomorphology 53: 333-337. 
Van Dijk WM, van de Lageweg WI, Kleinhans MG. 2013. Formation of a cohesive floodplain in a dynamic experimental meandering river. Earth Surface Processes and Landforms 38: 1550-1565.

Wilcock DN. 1971. Investigation into the relations between bedload transport and channel shape. Geological Society of America Bulletin 82: 2159-2176.

Wilkie K, Clague JJ. 2009. Fluvial response to Holocene glacier fluctuations in the Nostetuko River valley, southern Coast Mountains, British Columbia. In Periglacial and Paraglacial Processes and Environments, Knight J, Harrison S (Eds). Geological Society, London, Special Publication 320; 199-218.

Wolman MG. 1954. A method of sampling coarse river-bed material. Transaction of the American Geophysical Union 35: 951-956. 


\begin{tabular}{|c|c|c|c|c|c|c|c|c|}
\hline \multicolumn{5}{|c|}{ Channel flow and geometry data } & \multicolumn{4}{|c|}{ Sediment and slope data } \\
\hline 2001 Terrace & Min & Mean & Max & sd & 2001 Terrace & Min $D_{50}$ & Mean D50 & $\operatorname{Max} D_{50}$ \\
\hline Q & 61.18 & 64.49 & 67.69 & 3.25 & D50 & 0.1 & 0.144 & 0.171 \\
\hline $\mathrm{v}$ & 1.38 & 1.77 & 2.25 & 0.43 & sd & 0.047 & 0.103 & 0.126 \\
\hline w & 32 & 36 & 42 & 4.12 & $\mathrm{cv}$ & 0.476 & 0.719 & 0.78 \\
\hline $\mathrm{d}$ & 0.93 & 1.01 & 1.11 & 0.085 & & & & \\
\hline 2009 West & Min & Mean & $\operatorname{Max}$ & sd & 2009 West & Min $D_{50}$ & Mean $D_{50}$ & $\operatorname{Max} D_{50}$ \\
\hline Q & 53.95 & 71.26 & 85.08 & 10.25 & D50 & 0.059 & 0.117 & 0.159 \\
\hline $\mathrm{v}$ & 1.33 & 1.47 & 2.11 & 0.25 & $\mathrm{sd}$ & 0.021 & 0.067 & 0.099 \\
\hline $\mathrm{w}$ & 28 & 49.9 & 75 & 13.43 & $\mathrm{cv}$ & 0.328 & 0.574 & 0.656 \\
\hline $\mathrm{d}$ & 0.59 & 0.97 & 1.66 & 0.31 & & & & \\
\hline 2009 East & Min & Mean & Max & sd & 2009 East & Min $D_{50}$ & Mean D50 & $\operatorname{Max} D_{50}$ \\
\hline Q & 14.1 & 17.73 & 23.1 & 4.53 & D50 & 0.052 & 0.079 & 0.095 \\
\hline $\mathrm{v}$ & 0.85 & 1.02 & 1.2 & 0.18 & sd & 0.019 & 0.037 & 0.049 \\
\hline w & 17.25 & 20.5 & 27.6 & 3.1 & $\mathrm{cv}$ & 0.288 & 0.471 & 0.568 \\
\hline $\mathrm{d}$ & & 0.85 & & & & & & \\
\hline \multicolumn{5}{|c|}{ Sites estimated by extrapolation } & Surface & & Slope & \\
\hline & $\mathbf{Q}$ & $\mathbf{w}$ & d & $\mathbf{v}$ & West 2003 & & 0.007433 & \\
\hline 1998 tce & 62.58 & 60 & 0.6 & 1.74 & West 2009 & & 0.007433 & \\
\hline 1999 tce & 63.21 & 33.3 & 1.04 & 1.83 & East 2009 & & 0.003052 & \\
\hline 2000 tce & 63.85 & 34.6 & 1.03 & 1.79 & Proximal 1998 & & 0.013048 & \\
\hline 2002 tce & 65.14 & 37.4 & 0.99 & 1.76 & Proximal 1999 & & 0.009551 & \\
\hline 2003 tce & 65.79 & 38.9 & 0.98 & 1.73 & Proximal 2000 & & 0.007489 & \\
\hline \multirow[t]{2}{*}{2003 west } & 65.79 & 49.91 & 0.97 & 1.47 & Proximal 2001 & & 0.003819 & \\
\hline & & & & & $\begin{array}{l}\text { Proximal } 2002 \\
\text { Proximal } 2003\end{array}$ & & $\begin{array}{l}0.003426 \\
0.002971\end{array}$ & \\
\hline
\end{tabular}

Table 1: Summary of data used to construct Figure 6, including discharge (Q), velocity (v),

width (w), depth (d), mean grain-size (D50) and slope. Variability in the data is expressed using the minimum, mean and maximum values observed for each terrace surface, and standard deviation (sd) or coefficient of variation (cv). Descriptions of the survey methods used to collect the data, and the methods used estimate the values derived from extrapolation are given in the text. All lengths are in metres, slope is expressed as a ratio $(\mathrm{m} / \mathrm{m})$, and discharges are in $\mathrm{m}^{3} \mathrm{~s}^{-1}$. 


\section{Figure captions}

Figure 1: Major geomorphological landsystems of the Skaftafell region, showing the relation between the current active outwash surfaces and moraine belts and inactive outwash. Boxed area shows the location of Figure 2. Inset: map showing location of main map within Iceland.

Figure 2: Location map of the margin of Skaftafellsjökull, showing the major proglacial river channels and moraines. The glacier position shaded dark grey shows the 2008 location, the mid grey shows 2003, and the light grey shows 1997 . The extent of proglacial lakes is shown for 2008. The river channel in black is the 2008 channel, the mid grey channel shows 2002 , and the pale grey with dots shows the 1997 channel. The stippled shading beyond the glacier indicates the major moraine belts.

Figure 3: Advance and retreat of Skaftafellsjökull, from 1942 to 2010, from the database of the Icelandic Glaciological Society (provided by Oddur Sigurðsson).

Figure 4: Skaftafellsjökull margin in 2004, showing the location of the river channels and terrace fragments surveyed in this study. The eastern river channel is marked with a dashed line.

Figure 5: A) Long profile of the western and eastern river channels. The upper dashed line is the western channel in 2003 and the solid black line is the channel last occupied in 2009. The lower, grey line is the eastern river channel (surveyed in 2011). B) Long profiles of the terrace fragments shown in Figure 3. 
Figure 6: Channel pattern discrimination diagrams. In all diagrams, the black diamond is the 2003 western channel, the grey circle is the 2008 western channel, the black triangle is the eastern channel, and the crosses are the 1998 to 2003 proximal terraces. A) Leopold and Wolman (1957) discharge-slope diagram; B) Parker (1976) stability diagram; C) stream power - channel width-depth ratio; D) van den Berg (1995) stream power - grain size diagram. 


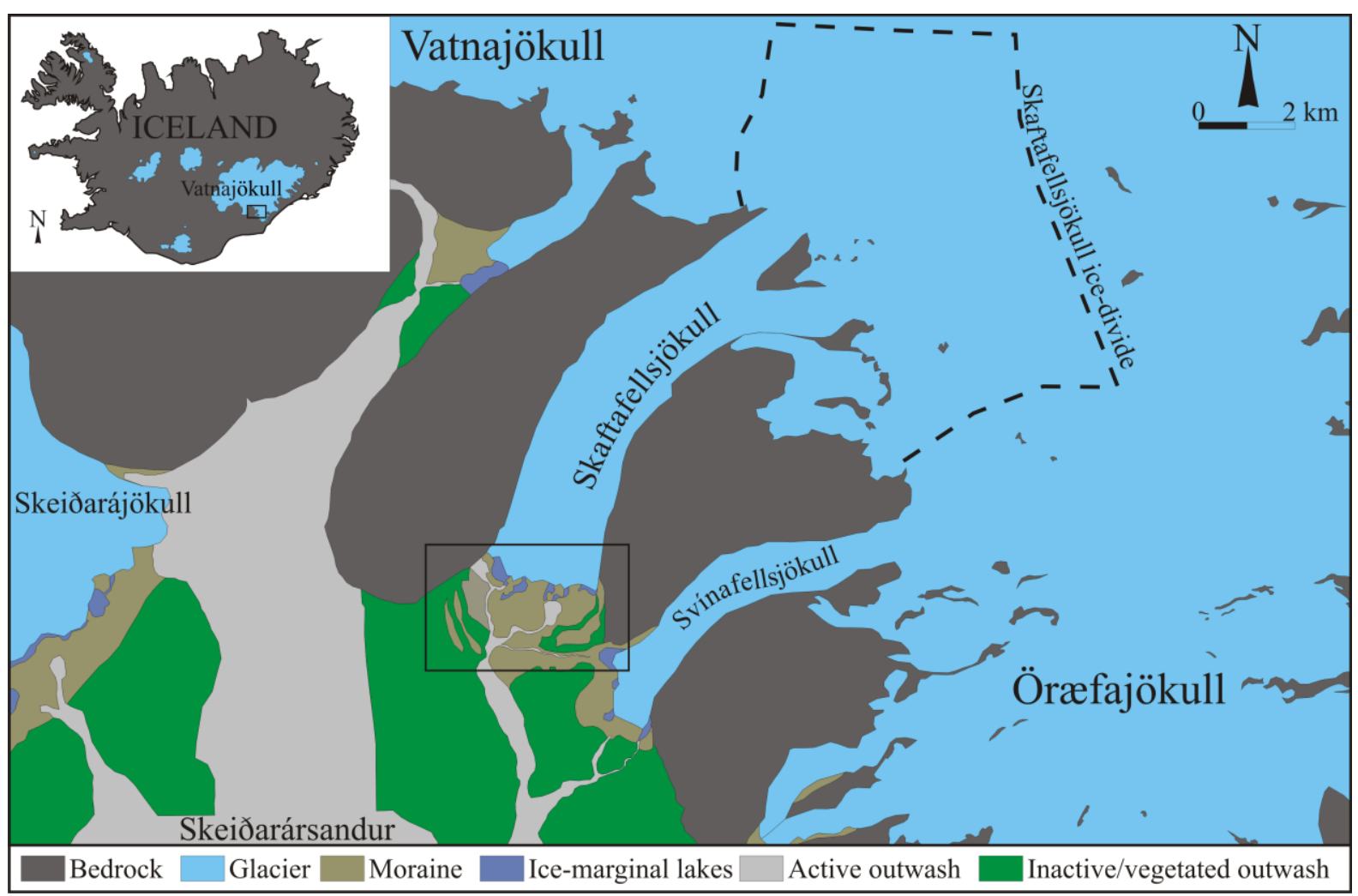

Figure 1. 


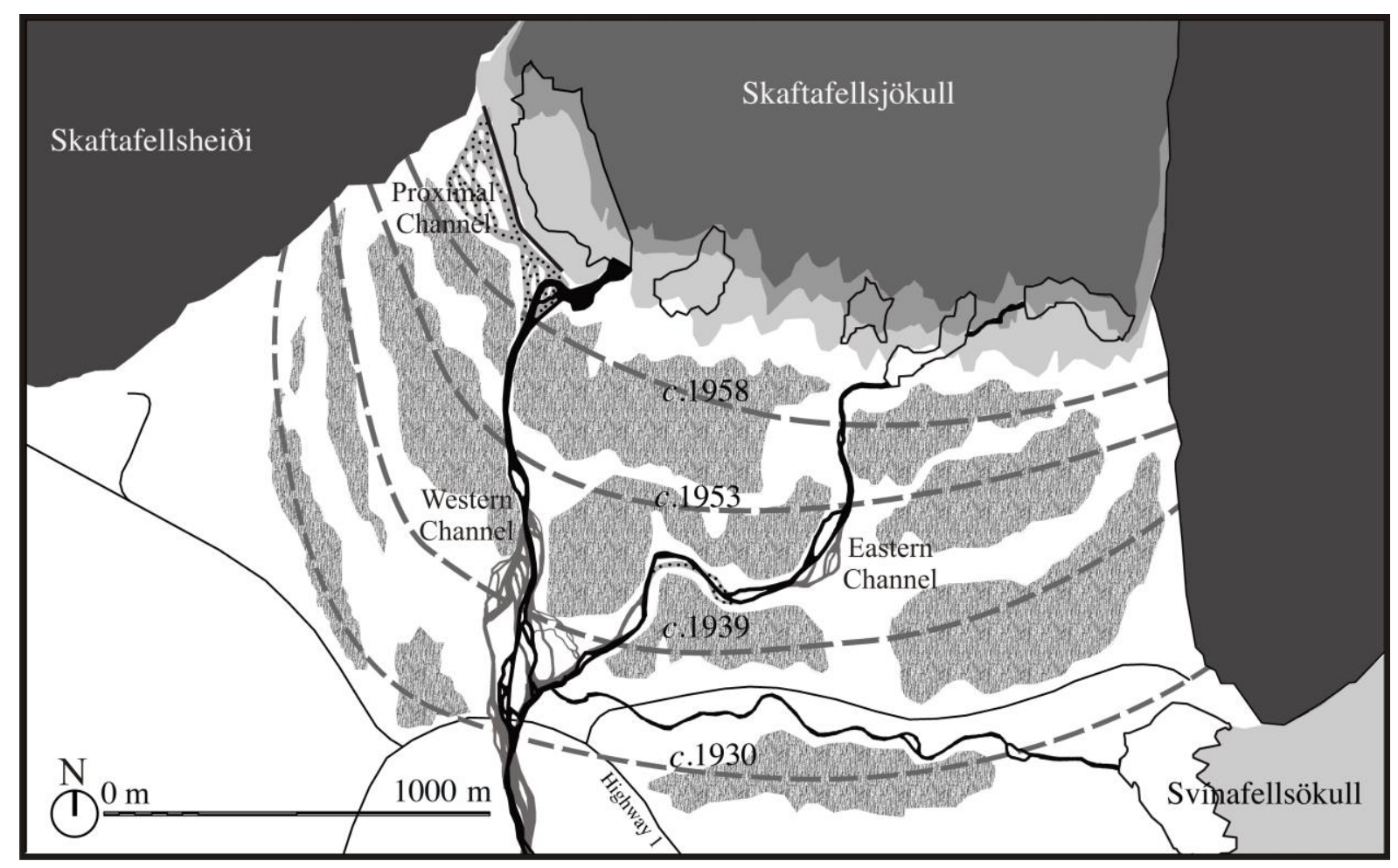

Figure 2. 


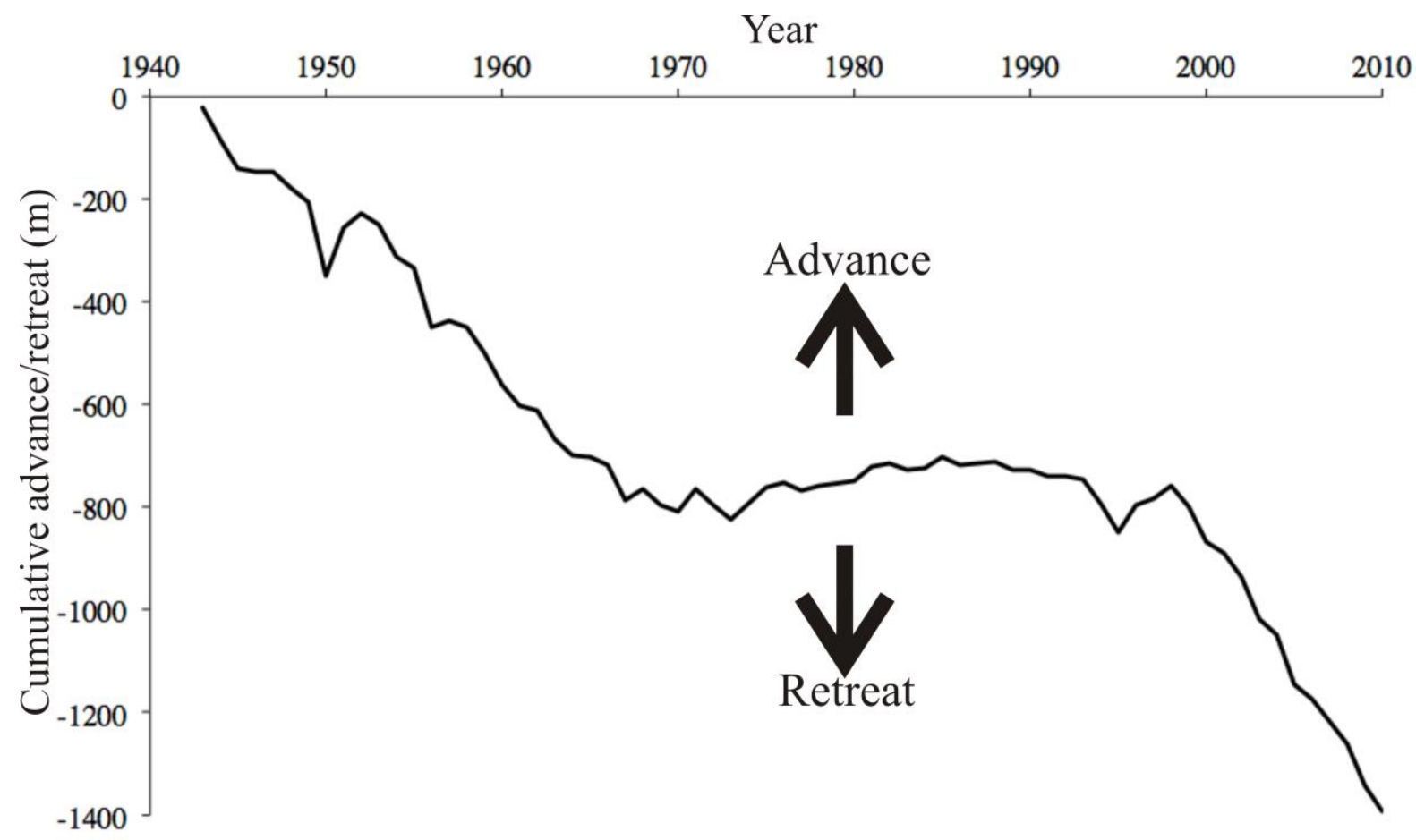

Figure 3. 


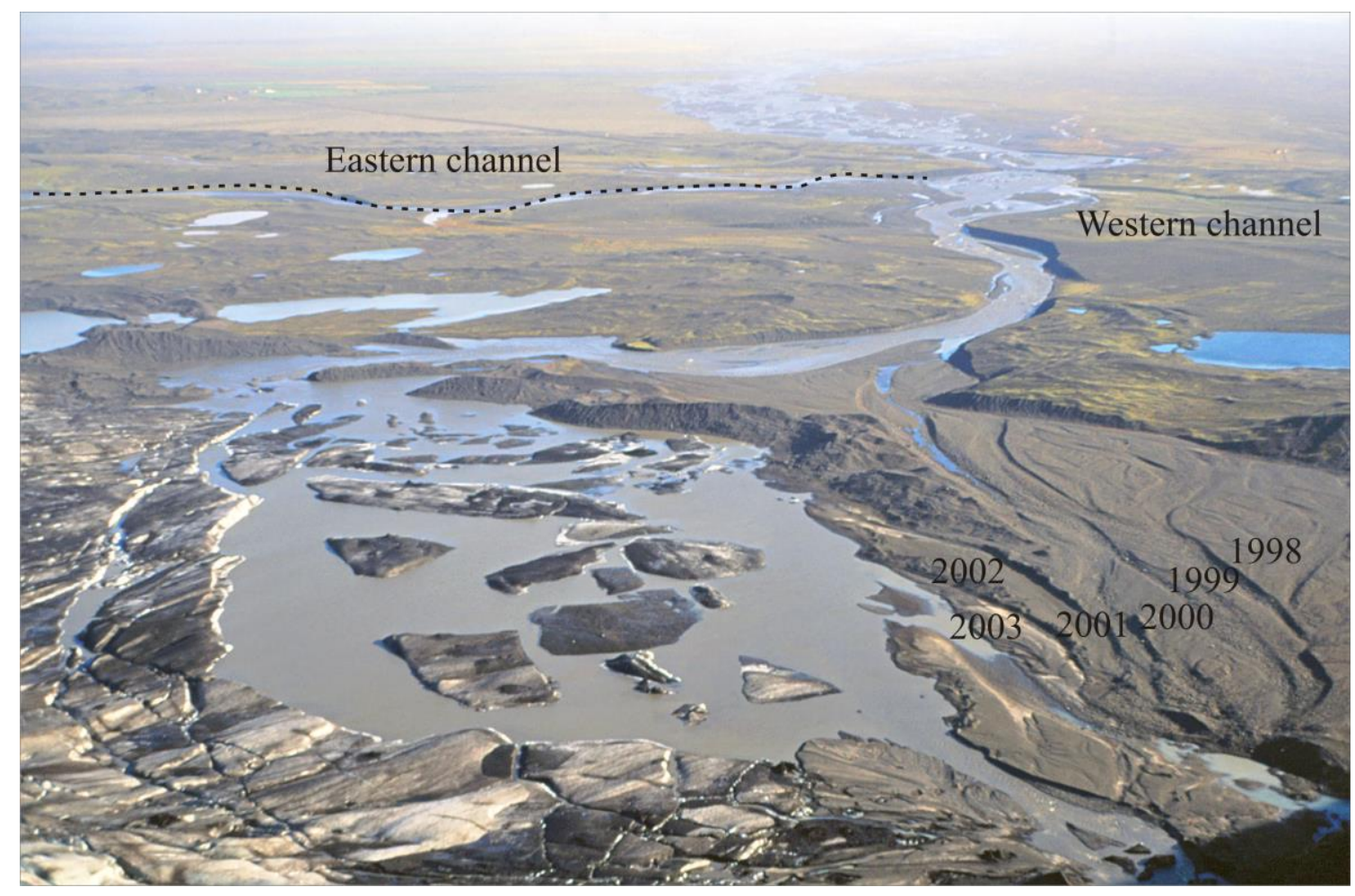

Figure 4. 

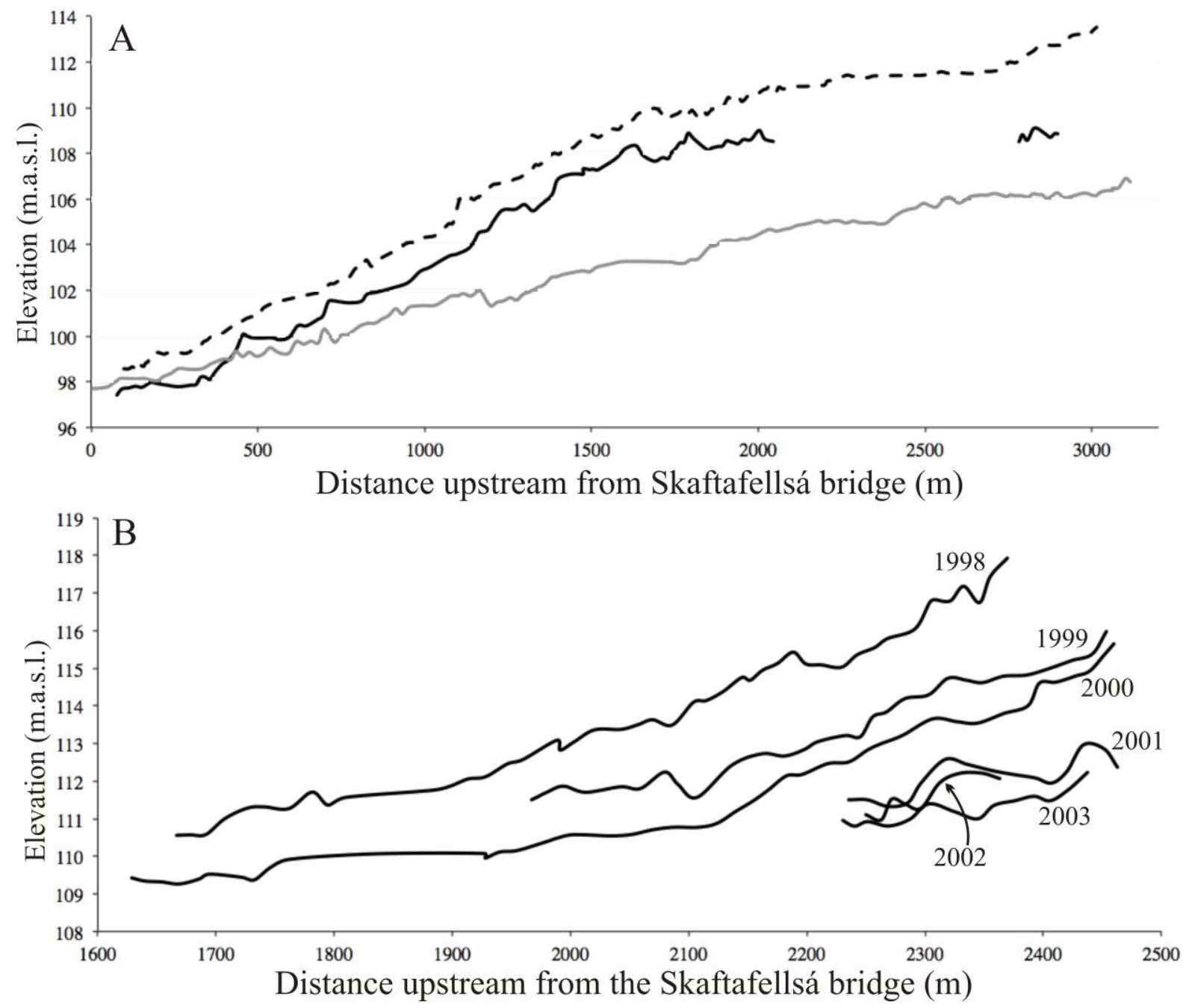

Figure 5. 

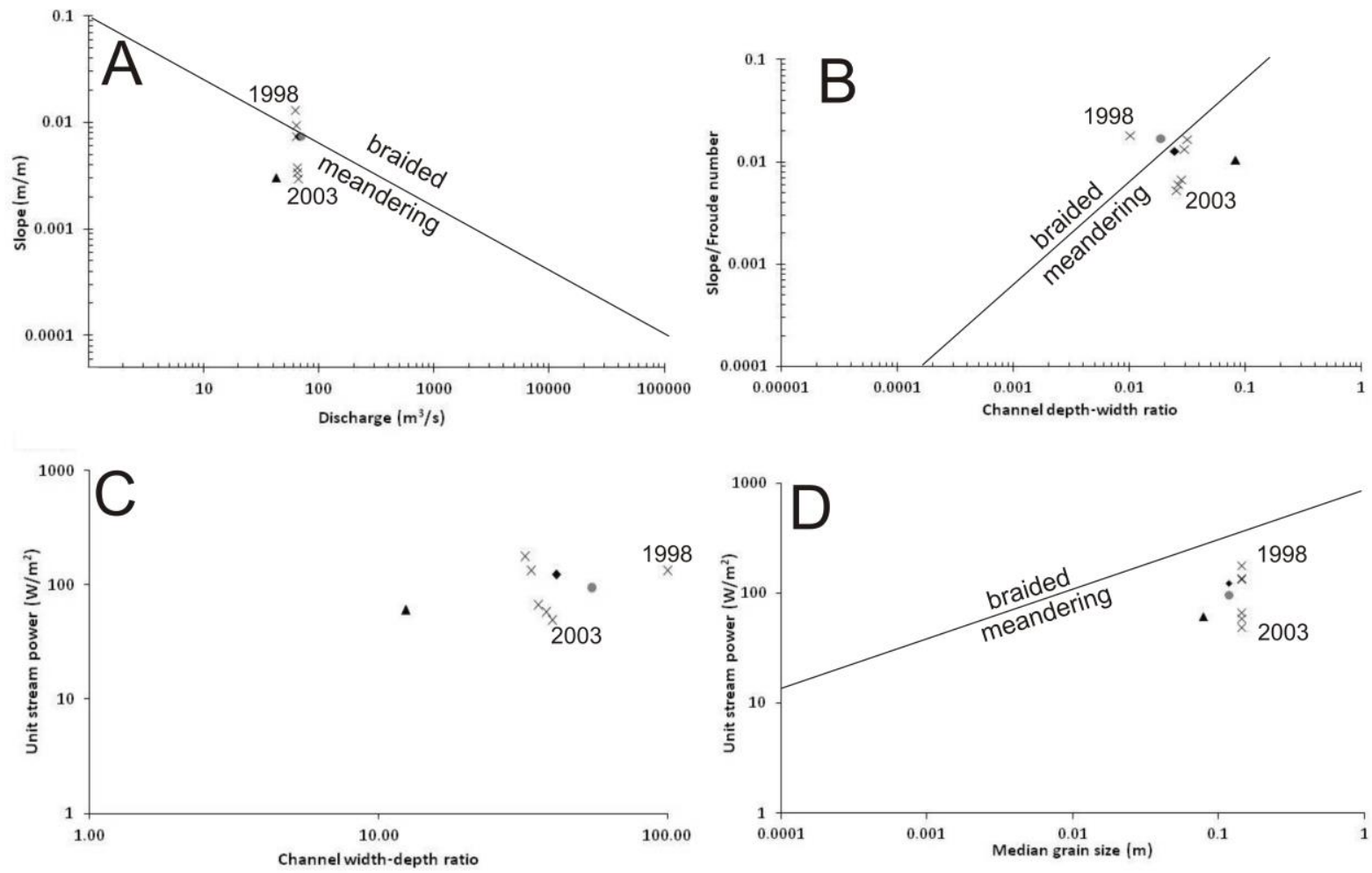

Figure 6. 